\title{
Active, middle, and passive: the morpho-syntax of Voice*
}

\author{
Artemis Alexiadou \\ Universität Stuttgart \\ artemis@ifla.uni-stuttgart.de
}

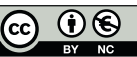

Received: June 30, 2014

Accepted: September 29, 2014

\begin{abstract}
This paper is concerned with the variation found with respect to how languages morphologically mark argument structure (AS) alternations, a variation that I take to be related to the realization of the syntactic Voice head. The paper discusses the behavior of dispositional middles and reflexives in languages such as English as opposed to their Greek counterparts. I will pursue the hypothesis that there are three Voice related heads implicated in AS alternations across languages. Active Voice is involved in the structure of all transitive and unergative predicates across languages, which in English subsumes d. middles and reflexives. Passive Voice, which the paper will only briefly touch upon here, takes as an input a transitive structure and gives an English/German/ Hebrew type passive. Middle Voice is the non-active counterpart of Kratzer's active Voice and gives rise to reflexives, passives and dispositional middles in Greek type languages.
\end{abstract}

Keywords: Voice; dispositional middles; reflexives; anticausatives; Passive; Middle; unergative; unaccusative; by-phrase.

Resum. Activa, mitjana i passiva: la morfosintaxi de la veu

Aquest article tracta la variació que mostren les llengües en el marcatge morfològic dels canvis en l'estructura argumental (EA), una variació que considero que està relacionada amb la realització del nucli sintàctic Veu. L'article estudia el comportament de les construccions mitjanes disposicionals i de les reflexives en llengües com l'anglès, en contrast amb les seves construccions corresponents en grec. Desenvoluparé la hipòtesi que darrere de les alternances en l'EA hi ha implicats tres nuclis Veu relacionats. El nucli Veu activa és a la base de l'estructura de tots els predicats transitius i inergatius de totes les llengües, que en el cas de l'anglès inclou les mitjanes disposicionals i reflexives. El nucli Veu passiva, que aquest article tractarà de manera molt breu, pren com a input una estructura transitiva i genera una passiva en llengües del tipus anglès/alemany/hebreu. El nucli Veu mitjana és l'homòleg no actiu del Veu activa de Kratzer i produeix reflexives, passives i mitjanes disposicionals en llengües del tipus grec.

Mots clau: veu; mitjanes disposicionals; reflexives; anticausatives; passiva; mitjana; inergatiu; inacusatiu; complement agent.

* My research was supported by a DFG grant to project B6 Underspecification in Voice systems and the syntax-morphology interface, part of the collaborative research center 732 Incremental Specification in Context at the University of Stuttgart. Many thanks to Terje Lohndal, Florian Schäfer, Giorgos Spathas, and two anonymous reviewers for comments and discussion. 


\section{Table of Contents}
1. Introduction
4. Towards an analysis
2. Dispositional middles across
5. Conclusions
languages
References

3. Reflexives across languages

\section{Introduction}

The term Voice is used at least in three ways in the literature. First, it denotes a particular alternation in a verb's argument structure. I will refer to such alternations as AS alternations here. Second, as Voice alternations are typically marked on the verb's morphology, Voice is considered a morpho-syntactic category of the verb. I will use the term Voice morphology to refer to the realization of Voice. Third, Voice is taken to be a syntactic head introducing the verb's external argument. Ever since the introduction of this head in Kratzer (1996), several authors have been dealing with the question of how AS alternations relate to this syntactic head, and what Spell-out conditions this is subject to, the main concern being the manner in which AS alternations relate to Voice morphology. This paper is couched within this tradition and attempts to offer an account of how Kartzer's Voice head relates to the realization of Voice in the context of Voice alternations, by paying particular attention to the crosslinguistic variation found with dispotional middle and reflexive formation.

As is well known, there are several AS alternations which have been thoroughly discussed in the literature. A central AS alternation is the one between active Voice and the eventive passive Voice, exemplified in (1) for English:

(1) a. John read the book.

(active)

b. The book was read (by John).

(passive)

Three further AS-alternations that have been the subject of much controversy are: (i) the causative-anticausative alternation. Anticausative predicates refer to spontaneous events like break, open, or melt which can also be construed as transitive/causative verbs. It is generally agreed upon that the transitive counterpart of the alternation is interpreted roughly as 'cause to verb intransitive , see Levin (1993), and Schäfer (2009) for discussion:

(2) a. John broke the vase.

(causative)

b. The vase broke.

(anticausative)

(ii) The generic or dispositional middle alternation (d. middle henceforth). According to Levin (1993:26), the intransitive variant of this alternation, the d. middle construction in (3b), is characterized by lack of specific time reference and by 
an understood but an unexpressed agent. D. middles tend to, and in some languages must, include an adverbial or a modal element. It is precisely these properties that distinguish the $\mathrm{d}$. middle alternation from the causative-anticausative alternation (see Schäfer 2008 for a detailed comparison):

(3) a. The butcher cuts the meat.

b. The meat cuts easily.

(iii) The reflexive alternation. This alternation involves naturally reflexive verbs, e.g. 'body care verbs' in Kemmer's (1993) classification (wash, comb), or 'verbs of assuming position' (sit down, turn), which can have transitive construals. The intransitive variant in this case, (4a), describes an action which is directed towards the subject of the verb.

(4) a. John washed and combed every morning.

b. John washed Mary.

The above AS-alternations have distinct properties. In the passive, there is general consensus that the external argument is somehow implicitly present, while this is not the case in anticausatives. In d. middles, the implicit external argument is less active than in the case of passives, but it is somehow understood. For instance, unlike passives, d. middles in English do not allow modification by agentive adverbials, control into purpose clauses, and they do not tolerate the licensing of the by-phrase. In addition, d. middles are generally considered to be stative predications. In the case of natural reflexives, reference is being made to two thematic roles that are both attributed to a single DP.

What will constitute the focus of my discussion here is the observation that we find a lot of variation in how languages morphologically mark these AS alternations, a variation that I take to be related to the realization of the syntactic Voice head. In English, the passive is analytic, built on the basis of an auxiliary and a participle, while the other three AS alternations bear active morphology. In languages such as Greek, intransitive variants of all alternations are formed synthetically and bear non-active morphology, i.e. passives, anticausatives, $d$. middles and reflexives are all marked alike, see (5), and Tsimpli (1989), Alexiadou \& Anagnostopoulou (2004), Zombolou (2004) for further discussion. ${ }^{1,2}$ In German and Romance, the passive is formed as in English, analytically, and d. middles, reflexives, and anticausatives are marked alike: they surface with a reflexive weak pronoun/clitic ( sich in e.g. German, see (6), and se in e.g. French), though as in Greek, see ftn. 1,

1. Note, however, that there are several anticausative verbs surfacing with active morphology similar to their English counterparts, see Alexiadou \& Anagnostopoulou (2004), Alexiadou, Anagnostopoulou \& Schäfer $(2006,2015)$ for discussion.

2. Note that Greek can form transitive versions of reflexive predicates via the complex reflexive DP ton eafto tu, which is generally considered to be a DP internal argument of the predicate, see Iatridou (1988), Anagnostopoulou \& Everaert (1999), Spathas (2010) for discussion. 
there are several anticausatives that surface with active morphology. The number of so-called unmarked anticausatives differs from language to language and will not be of concern here. The reader is referred to Alexiadou, Anagnostopoulou \& Schäfer $(2006,2015)$ for details.

(5) a. O Janis ekapse ti supa.

(active)

the John-nom burnt-3sg the soup-acc

'John burnt the soup.'

b. To vivlio diavastike apo to Jani.

(passive)

the book read-NAct by the John

'The book was read by John.'

c. I supa kaike.

(anticausative)

the soup-nom burnt-NAct-3sg

'The soup burnt.'

d. I Maria htenistike.

the Mary-nom combed-NAct-3sg

'Mary combs (herself).'

e. Afto to vivlio diavazete efkola.

this the book-nom reads-NAct-3sg easily

'This book reads easily.'

(6) a. Der Mann wäscht sich.

the man washes REFL

'The man washes himself.'

(reflexive)

b. Diese Art von Büchern verkauft sich immer gut. (d. middle) this sort of books sells REFL always well 'This sort of books sells always well.'

c. Die Tür öffnete sich.

(anticausative)

the door opened REFL

'The door opened.'

d. Die Tür wurde geöffnet.

the door was openened

(reflexive)

'The door was openened.'

(passive)

Table 1 summarizes the cross-linguistic variation found. This table includes Hebrew, which is like English and German in having a distinct passive, but like Greek in that its passive is synthetic. As discussed in Doron (2003), Hebrew marks d.middles, reflexives and anticausatives with middle Voice morphology, at least in its intensive template, while its simple template shows a syncretism identical to that of Greek.

In this paper, I will discuss two points of variation. The first one concerns the behavior of d. middles in languages such as English as opposed to their Greek counterparts, building crucially on Lekakou's (2005) insights. The second one concerns 
Table 1. Voice syncretism across languages

\begin{tabular}{lcccccc}
\hline & active & $\begin{array}{c}\text { analytic } \\
\text { passive }\end{array}$ & $\begin{array}{c}\text { synthetic } \\
\text { passive }\end{array}$ & $\begin{array}{c}\text { dispositional } \\
\text { middle }\end{array}$ & anticausative & reflexive \\
\hline Greek & Act & - & Nact & Nact & Nact & Nact \\
\hline Hebrew & Act & - & Pass & Middle & Middle & Middle \\
\hline German & Act & + & - & Refl & Refl & Refl \\
\hline Romance & Act & + & - & Refl & Refl & Refl \\
\hline English & Act & + & - & Act & Act & Act \\
\hline
\end{tabular}

the behavior of reflexives in English as opposed to Greek, building on Alexiadou \& Schäfer (2013). I will not deal with cross-linguistic differences in the domain of passives and anticausatives and refer the reader to Alexiadou (2013), Alexiadou, Anagnostopoulou \& Schäfer (2006, 2015), and Spathas, Alexiadou \& Schäfer (to appear) for details and an analysis.

I will concentrate on $\mathrm{d}$. middles and reflexives for two reasons: first, they show distinct morpho-syntax in the two languages I am mainly interested in, namely Greek and English. In Greek, they surface with non-active morphology, which is shared by e.g. passives, while in English they surface with active morphology. The question I will ask is how these realizations relate to the syntactic head Voice. The study of these patterns is of theoretical importance, as it addresses the relationship between syntax and the lexicon. In some of the recent literature, the cross-linguistic differences between passives, reflexives and $d$. middles across languages have been explained in terms of the Lexicon vs. Syntax parameter, from Reinhart \& Siloni (2005):

(7) UG allows thematic operations to apply in the lexicon or in the syntax.

For instance, Papangeli (2004) argues that with respect to reflexivization Greek is a syntax language, while English is a lexicon language. Earlier literature proposed that passives in Greek are lexical and not syntactic, see e.g. Smyrniotopoulos (1992). This parametrization is supposed to explain the differences in terms of productivity and syntactic behavior of AS alternations across languages.

My account is couched within the framework of Distributed Morphology, which rejects (7) and adopts the Borer/Chomsky conjecture in (8). The functional head in our case is Kratzer's Voice head:

(8) Parametrization is related to properties of functional heads.

In particular, I will pursue the following hypothesis, developed in Doron (2003), Alexiadou \& Doron (2012), and Spathas, Alexiadou \& Schäfer (to appear): there are three Voice related heads implicated in AS alternations across languages. Active Voice is involved in the structure of all transitive and unergative predicates across languages (which in English subsumes d. middles and reflexives). Passive Voice, which I will only briefly touch upon here, takes as an input a transitive 
structure and gives an English/German/Hebrew type passive. Middle Voice is the non-active counterpart of Kratzer's active Voice and gives rise to reflexives, passives and d. middles in Greek type languages. Following Doron's insights, I take Middle Voice to crucially differ form Passive in that it does not obligatorily trigger a Disjoint Reference Effect. This explains why eventive passives, reflexives, and d. middles do not show a uniform syntactic behavior across languages. The locus of Voice morphology is the functional head Voice, building on Kratzer (1996), the projection which introduces the external argument. In the absence of an external argument, as is the case of unmarked anticausatives, see ftn. 1, no Voice projection is present and the default morphology is active, see Alexiadou, Anagnostopoulou \& Schäfer $(2006,2015)$ for discussion. In contrast, the active morphology of English is related to the presence of an active Voice head, the single argument of these predicates being projected in its specifier, contra e.g. Alexiadou \& Doron (2012), Schäfer (2008). As we will see, in English both d. middles and reflexives behave like unergative predicates, while they behave like unaccusatives in Greek. This is precisely related to the distinct morpho-syntactic representation of these predicates in the two languages.

The novelty of the proposal relies primarily in the application of the Middle Voice approach to Greek d. middles, by relating it to Lekakou's important findings. Moreover, the paper makes the claim that since middle Voice is actually a non-active Voice head, AS alternations that surface with active morphology, such as English d. middles and reflexives, cannot involve a Middle Voice head, contra Alexiadou \& Doron (2012). Furthermore, the paper contributes to our understanding of how the morpho-syntactic properties of AS alternations relate to their semantics: while English d. middles and reflexives have the same morphological realization as anticausatives in this language, they differ in terms of structural representation. Anticausatives lack a Voice projection, while d. middles and reflexives contain an active Voice head. And while English d. middles and reflexives differ in terms of morpho-syntactic properties from their Greek counterparts, they form a unified semantic class. From this perspective, d. middle is a particular interpretation that certain syntactic configurations may give rise to, crucially following Condoravdi (1989), Lekakou (2005), and Pitteroff (2014) among others.

The paper is structured as follows: in section 2, I discuss the different morphosyntactic properties of d. middles in English and in Greek; in section 3, I turn to the morpho-syntactic differences between English and Greek reflexives. In section 4, I propose my analysis of these differences. In section 5, I conclude and address some wider implications of the analysis as well as the question how this analysis can be applied to the other languages included in table 1.

\section{Dispositional middles across languages}

In what follows, I briefly outline Lekakou's (2005) proposal, which instantiates a novel way to approach the relationship between the semantics and the morphological realization of d. middles across languages. According to Lekakou, middles ascribe a dispositional property to the understood object. This has as a result that 
the subject of a middle sentence will never be an agent. From her perspective, disposition ascriptions are subject-oriented generic sentences. She points out that the core properties that middles share across languages follow: the genericity of an otherwise eventive predicate; the promotion to subject position by syntactic movement or base-generation, and the interpretation of the otherwise internal argument; the demotion and interpretation of the otherwise external argument. For Lekakou (2005: 1), 'the crosslinguistic variation relates to the following two factors. First, the different means available to languages to encode genericity distinguishes between unergative and unaccusative middles. Unaccusative middles obtain in languages like French and Greek, which encode genericity in the morphosyntax in the form of imperfective aspect. Languages where genericity is not expressed by aspectual morphology, i.e. German, Dutch and English, employ unergative structures.'

This proposal enables us to approach the cross-linguistic differences in the realization of middles in an insightful way. As is well known, d. middles do not behave syntactically uniformly across languages, although they form a unified semantic class. In English, as Ackema \& Schoorlemmer (1994) have shown, they exhibit properties of unergatives. On the other hand, in Greek, d. middles are formally identical to passives, i.e. they are unaccusative predicates. In what follows, I will review the evidence in favor of this partition. To begin with, d. middles in Greek tolerate by phrases (Tsimpli 1989, Lekakou 2005):

(9) Afto to vivlio diavazete efxarista. (apo opiondipote) this the book read-NAct-Imperf-3sg with-pleasure by anyone 'This book reads with pleasure by anyone.' [lit.]

While by-phrases are out in English, see (10), (11) shows that a for-PP can be used in the dispositional middle relating to the implicit external argument. Stroik $(1992,1999)$ argues that the presence of for-phrases signals that the agent argument of the verb is syntactically present and the agent has been demoted to a VP adjunct.

(10) *Plates break easily by John.

(11) Bureaucrats bribe easily for Sam.

Recently, however, Stephens (2007) showed that for-PPs can appear with unergative verbs, which d. middles in English will be shown to be, see below, and with instrument subject constructions, see (12). These constructions are significant as they suggest that the for-PP cannot realize the verb's external argument since this is projected in the syntax (for a detailed discussion of instrument subjects see Alexiadou and Schäfer [2006]):

(12) a. Ed has no trouble getting the baby to sleep, but she won't sleep for me.

b. This pen draws nice lines for any decent calligrapher. 
Semantically, the for-PP introduces objects that act volitionally and seem to exercise control over the eventuality, but crucially the primary responsibility of action is attributed to the grammatical subject and not to the object of the for-PP. Stephens concludes that the association of the object of the for-PP with the agent of dispositional middles seems to be a pragmatic, rather than a syntactic, phenomenon, see also Alexiadou (2012) for some further discussion.

Turning now to the arguments that have been put forth to show that $\mathrm{d}$. middles are unergative in English but unaccusative in Greek, consider the following. A first argument discussed in Lekakou, due to Edwin Williams (personal communication) and Fellbaum (1986), involves pairs such as raise-rise, see also Schäfer (2008) for discussion. These pairs are interesting as they involve variants of the causative-anticausative alternation which are morphologically distinct. The intransitive variant of raise is rise in (13b). Crucially, the d. middle does not employ the unaccusative form, it employs the transitive form (13c): ${ }^{3}$

(13) a. John raises his kids very strictly.

b. The sun rises from the East.

c. Obedient daughters raise more easily than disobedient sons.

To account for this, I will assume, following Embick (2010), that phasal heads trigger a particular Spell Out of roots. In this case, the relevant phase head is Voice, see Schäfer (2008). According to Alexiadou, Anagnostopoulou \& Schäfer (2006, 2015) and Schäfer (2012), both causatives and anticausatives are bi-eventive (in the sense that they involve two eventualities, one verbal event $\mathrm{v}$ and a Result State, see (14a-b)). From this perspective, causative predicates differ from anticausatives in that the former contain a Voice layer (Kratzer 1996) introducing an external argument, which the latter lack:
a. [Voice [v [ STATE ]]]
(causative)
b.
$[\mathrm{v}[\mathrm{STATE}]]$
(anticausative)

Thus it is precisely the presence vs. absence of the Voice layer that triggers the stem alternation in (13), since unergatives, like transitive predicates, contain the functional layer Voice introducing the external argument.

A second test involves the formation of prenominal participles. D. middles, unlike unaccusatives, cannot form prenominal modifiers:

(15) a. *the easily bribing men

b. the swiftly rolling ball

3. The fact that agent subjects are out in middles is explained by Lekakou's (2005) proposal briefly summarized in the beginning of this section. 
On the basis of the above, we can thus conclude that English d. middles behave like unergative predicates.

Turning to Greek, although the language lacks most of the standard tests for unaccusativity (see Markantonatou 1992, Alexiadou \& Anagnostopoulou 1999), the following tests suggest that $d$. middles pattern with unaccusatives. A first test discussed in Lekakou (2005), and see also Sioupi (1998), is compatibility with postverbal bare plurals. Only unaccusatives tolerate such subjects, unergatives do not, see Alexiadou \& Anagnostopoulou (1999), and Alexiadou (2011). When we apply this test to d. middles, we see that the middle interpretation of (16) is unavailable, from Lekakou (2005):
*Vleponde tenies. watch-NAct-Imperf-3plfilms
'Films are watched.'

On the basis of this test, $d$. middles should be analyzed as unergative predicates. However, as noted by Alexiadou (1999), postverbal subjects are illicit with stative verbs in general. Thus due to its genericity, according to Lekakou (2005), the middle verb is of (derived) stative aspect, hence it is unlikely that it can tolerate a postverbal subject. We then conclude that the above test does not provide evidence against the analysis of Greek d. middles as unaccusatives, but is attributable to a conflict between unaccusative derivation and stativity.

A second test involves possessor sub-extraction, which is possible from the post-verbal subject of an unaccusative verb, as well as from the object of a transitive but not from the subject of an unergative (see Alexiadou \& Anagnostopoulou 1999). Lekakou (2005) shows that d. middles in Greek, like unaccusative predicates, allow possessor sub-extraction:
(17) a. tinos irthe to aftokinito? whose came-3sg the car 'Whose car came?'
b. tinos diavases to vivlio? whose read-2sg the book 'Whose book did you read?'
(18) *tinos kudunise to kuduni? whose rang-3sg the bell 'Whose bell rang?'
(19) tinos vleponde i tenies efkola? whose see-NAct-Imperf-3pl the film-Nom-Pl easily 'Whose movies watch easily?'

I thus conclude that $\mathrm{d}$. middles behave like unaccusatives in Greek. This being the case, we expect d. middles in this language to be subject to the same morphological requirement that all structures without an external argument are subject to, namely to surface with non-active morphology, see Embick (1998), a point to which I will turn in section 4. 
Before turning to reflexive predicates in the next section, however, let me point out that in agreement with Lekakou (2005) and Condoravdi (1989), I take d. middle to be a semantic category whose syntactic realization can differ across languages. Thus distinct morpho-syntaxes as in Greek and English can both yield the same semantics. Following Lekakou, the semantics of middles are licensed by imperfective morphology in Greek. Adopting her analysis, a language will employ an unaccusative structure for the middle interpretation iff genericity is encoded in imperfective morphology, as stated in (20), from Lekakou (2005). For Lekakou, imperfective morphology encodes genericity, and in languages such as Greek (and French) goes hand in hand with an unaccusative syntax. Languages such as English (and German, and Dutch), which do not encode genericity morphologically resort to an unergative type middle, see Lekakou (2005, chapter 3 for extensive discussion).

(20) A language encodes genericity in imperfective morphology iff in at least one tense it has two distinct verb forms for generic and non-generics uses, i.e. iff genericity $\rightarrow$ imperfectivity.

(21) Middle interpretation=the ascription of a dispositional property to the Patient/ Theme argument.

I will discuss in section 4 how English satisfies (21). What, however, I will not discuss here is how the genericity of an otherwise eventive verb and the obligatorily generic interpretation of indefinite subjects of middles is derived, as this is clearly beyond the scope of this paper. I refer the reader to Lekakou (2005) and Schäfer (2008) for details.

\section{Reflexives across languages}

Reflexive predicates in languages such as Greek are considered by several authors to function like unaccusatives (Marantz 1984, Embick 1998 and others), basically because they share the same non-active morphology with intransitive variants of verbs entering the causative alternation, which are uncontroversially unaccusatives, see (5) above, and (22) below, from Alexiadou \& Schäfer (2013).

(22) a. O Janis eplin-e ti Maria.

the John washed-3sg the Mary

'John washed Mary.'

b. I Maria pli-thik-e me prosohi.

the Mary washed-NAct-3sg with care

'Mary washed carefully.'

However, reflexives differ from anticausatives in that they have an agentive interpretation, and thus can be modified by agent-oriented adverbials (22b). In fact, several other scholars analyzed such predicates as unergatives (e.g. Papangeli 2004, 
Tsimpli 1989). Tsimpli (1989), in particular, discusses a diagnostic that suggests that the DP argument of reflexives is not a derived subject. According to Tsimpli, a derived subject in Greek cannot control into rationale clauses, as shown in the passive example in (23). In contrast, subjects of naturally reflexive predicates can (24). This suggested to Tsimpli that the subject in (24) cannot be analyzed as 'deep' object, and hence reflexives are unergative predicates. ${ }^{4}$

(23) *O Janis dolofonith-ik-e ja na gini iroas. the John murdered-NAct-3sg for subj become hero ' $\mathrm{John}_{\mathrm{i}}$ was murdered $\mathrm{PRO}_{\mathrm{i}}$ to become a hero.'

(24) I Maria htenist-ik-e ja na vgi ekso. the Mary combed-NAct-3sg for subj go out 'Mary combed $_{\mathrm{i}} \mathrm{PR}_{\mathrm{i}}$ to go out.'

Again as with d. middles, the following tests suggest that reflexives are actually unaccusatives and not unergatives in Greek. Markantonatou (1992) pointed out that in Greek unaccusative but not unergative predicates can form adjectival participles. Applying this diagnostic, we see that reflexives pattern unlike unergatives:

(25) a. pesmeno filo fallen leaf

(26) a. plimeno pedi washed child b. *tregmenos anthropos run man

b. ksirismenos anthropos shaved man

However, as Alexiadou \& Schäfer (2013) note, this only shows that reflexives behave unlike unergatives, not that they are necessarily unaccusative. (26a, b) could as well be derived from the transitive version of these verbs.

As in English, unergative predicates can build er-nominals in Greek, while unaccusatives cannot. The corresponding affix is -tis (27a-d), from Alexiadou \& Schäfer (2013). Applying this test to reflexives, the authors conclude that they pattern unlike unergative predicates. However, the following remarks are in order as far as this test is concerned. The formation of -er nominals in Greek is generally restricted. For instance, Zombolou (2004) observes that none of the verbs of the destroy/kill class can form -er nominals. Moreover, note that transitive variants of reflexive verbs cannot form such nominalizations for reasons that need to be

4. As an anonymous reviewer correctly points out, examples with unaccusative predicates in Greek are fine, similarly to (24), suggesting that unaccusatives and reflexives pattern on a par:

(i) irthan tehniki ja na episkevasun ton ipologisti came-3pl technicians for subj repair-3pl the computer 'Technicians ${ }_{i}$ came PROi to repair the computer.'

This suggests that the problem with (23) is the Control via the implicit argument of the passive, see the discussion in section 4.2. 
investigated further. Importantly, however, unergative predicates happily form -er nominals, see (27).

(27) a. tragudis-tis singer

(28) a. *ksiris-tis shaver b. horef-tis dancer

b. *ndi-tis dresser
$*$ pes-tis
faller

d. *erho-tis arriver

Turning now to one of the tests discussed above in the context of $\mathrm{d}$. middles, note that with respect to possessor sub-extraction, reflexive verbs pattern unlike unergatives:

(29) tinos plithikan ta pedia?

whose washed-NAct-3pl the children

'Whose children washed?'

Alexiadou \& Schäfer (2013) discuss a further test, namely the ellipsis test, which also suggests unaccusativity: (30a) with an overt object anaphor is ambiguous, the reflexive with non-active morphology in (30b) has only a sloppy reading and no object comparison reading. Sells, Zaenen \& Zec (1987) claim that this is so because a process of de-transitivization has taken place.

(30) a. O Janis pleni ton eafto tu perisotero apo to Vasili. the John washes him self more than the Vasili

'John washes himself more than Vasilis.'

1. Subject comparison, strict or sloppy

John washes himself more than Vasili washes John/himself

2. Object comparison: Shows that washes himself is transitive John washes himself more than he washes Vasili

b. O Janis plenete perisotero apo to Vasili.

the John washes-NAct more than the Vasilis

1. Sloppy interpretation: John washes himself more than Vasilis washes himself

2. no object comparison

On the basis of the above, Alexiadou \& Schäfer (2013) conclude that Greek reflexives are unaccusatives.

In contrast, English reflexives behave syntactically as unergatives. This point has already been made in e.g. Reinhart \& Siloni (2004), and Alexiadou \& Schäfer (2013) present some more arguments in favor of this analysis. Firstly, like unergatives (31a), but unlike unaccusatives (31b), they can appear in the X-wayconstruction (see Goldberg 1997, Marantz 1992). 
(31) a. John danced his way out of the room.

b. *The butter melted its way off the turkey.

c. John washed/shaved his way into a better job.

Secondly, resultative secondary predicates can only be predicated of internal arguments; in the absence of such an internal argument a (fake) reflexive has to be inserted (32). Again, reflexives show unergative behavior (again under both their interpretations) (33).

Thirdly, reflexives can build er-nominalization, which is impossible with unaccusatives (34). ${ }^{5}$

(32) a. The ice froze (*itself) solid.

b. John laughed *(himself) sick.

(33) a. John washed/shaved *(himself) clean.

b. John washed $*$ (something) clean.

(34) a She runs so fast because she is an experienced runner.

b * She moves so gracefully because she is an experienced mover.

c She dresses slowly because she is an elegant dresser.

Finally, as Alexiadou \& Schäfer (2013) point out, (35) with an object reflexive pronoun is three-way ambiguous and has an object comparison reading while (36), the corresponding reflexive, has only the sloppy reading. Importantly, it lacks the object comparison reading, which requires a transitive antecedent (Dimitriadis \& Que 2009).

(35) John washes himself better than George.

a. John washes himself more than George washes himself . (sloppy)

b. John washes himself more than George washes John. (strict)

c. John washes himself more than he washes George. (object comparison)

5. An anonymous reviewer suggests that one should be careful with the application of the $-e r$ test. Note that the context in (34) allows only the intransitive and not the transitive intepretation of the predicated. As already noted earlier in this section, the test is also problematic in Greek: naturally reflexive predicates do not form -er nominals neither in their transitive nor in their intransitive variant. 
(36) John washes more than George.

a. Subject comparison (sloppy):

John washes himself more than George washes himself.

a'. John washes more stuff than George washes stuff.

b. Object comparison: Impossible, showing that wash is intransitive.

*John washes himself more than he washes George.

While this test gives the same results in English and in Greek, one should not interpret its results as suggesting that reflexive predicates are identical with respect to intransitivity. In English, all the other tests show that the predicate is unergative, while in Greek we have an unaccusative structure. Crucially both structures are intransitive, but they differ with respect to unaccusativity/unergativity.

Summarizing, we have two distinct morpho-syntaxes corresponding to the same semantic category: in Greek d. middles and reflexives surface with non-active morphology, while they both surface with active morphology in English. Does this mean that in both languages the same syntactic head Voice is present in these alternations? We saw that in Greek, non-active morphology goes together with an unaccusative syntax, while in English active morphology goes together with an unergative syntax. This leads to the proposal that distinct Voice heads must be present in these two AS alternations in the two languages. In the next section, we will see how this can be captured in the theory of Voice developed in Alexiadou \& Doron (2012), and Alexiadou, Anagnostopoulou \& Schäfer (2015), Spathas, Alexiadou \& Schäfer (to appear).

\section{Towards an analysis}

\subsection{A theory of Voice}

I assume, building on Doron (2003), Alexiadou \& Doron (2012), Alexiadou, Anagnostopoulou \& Schäfer (2015) and Spathas, Alexiadou \& Schäfer (to appear), that there are three heads implicated in argument alternations of the type discussed here: active, middle, and passive. While the characterization that I will offer here does not correspond to that offered in these works, it will be sufficient to account for the cross-linguistic differences discussed in the previous sections.

My account of the patterns discussed in sections 2 and 3 is cast within the framework of Distributed Morphology, according to which word formation processes make use of the following units: roots, and functional morphemes, e.g. categorizing heads (v), the projection introducing the external argument (Voice), Aspect, Tense, etc. It is generally agreed upon that external arguments, and perhaps arguments in general, see Lohndal (2014), are introduced above these categorizing heads. Kratzer (1996) labels the projection that introduces external arguments Voice. In addition to introducing external arguments, Voice is a cyclic head in the sense of Embick (2010): it determines a special domain for interpretation and allomorphy, as we saw above in (13-14). 




Following Alexiadou \& Doron (2012), see also Bruening (2012), Collins (2005), Alexiadou, Anagnostopoulou \& Schäfer (2015), and Spathas, Alexiadou $\&$ Schäfer (to appear), I assume that there are two distinct non-active Voice heads implicated in AS alternations, Passive and Middle (Doron 2003). Passive attaches outside the domain that introduces the external argument and thus has as its input a transitive structure. This is the case in English (and German), Bruening (2012), cf. Collins (2005). Middle is located lower, i.e. it is the non-active counterpart of Voiceactive in (37), cf. Marantz (2013), see (38b): ${ }^{6}$

(38) a.

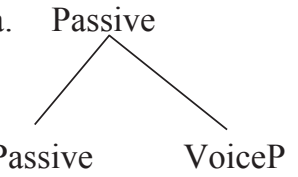

b.

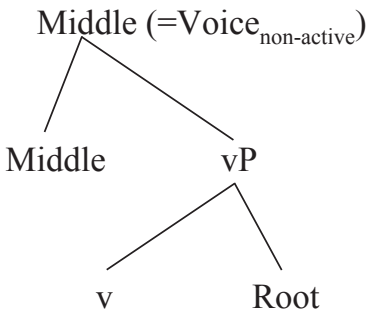

In languages such as English the passive head merges high, i.e. it is above the projection that introduces the external argument. In other words, in languages of this type passive is an operation on an active transitive verb phrase, and it derives passive VPs, see also Merchant (2013). Greek, on the other hand, as well as other languages of this type, lack this head. Their verbs ( $\mathrm{v}+$ root) combine only with Middle Voice, which is actually the non-active counterpart of Kratzer's Voice.

\subsection{Explaining cross-linguistic variation}

From the perspective of this model then, the proposal is that in Greek, and other languages of this type, the non-active Voice head under discussion will be realized with non-active morphology: in the absence of a specifier in Voice, which is the case with all intransitives, this head is spelled-out non-active (following Embick 1998). A structure such as the one in (38b) is thus underdetermined for

6. As correctly pointed out by an anonymous reviewer, it is not clear how such a theory of Voice can be applied to languages such as Icelandic that assign accusative in passive construals. It would seem that passive in these construals can embed a transitive structure, with a deficient external argument. The issue merits further investigation. 
the semantic interpretation it can receive: as Spathas, Alexiadou \& Schäfer (to appear) argue, depending on the type of root the structure contains, it can yield a reflexive or a passive interpretation. This crucially means that midle Voice is underspecified, which leads to ambiguity with the same root, unless the context provided further specification. The former interpretation is readily available with natural reflexive roots, the latter with natural disjoint predicates. Since this structure is underspecified, speakers are relatively free to choose an interpretation that would go along with it.

Turning now to the morpho-syntax of d. middles, Lekakou (2005) argued extensively that in Greek a d. middle interpretation has as an input a passive structure, i.e. a middle Voice structure of the type in (38b) in our terms. ${ }^{7}$ We can thus propose the following: structures such as the one in (38b) can be interpreted as reflexive, when they include a root belonging to the group of naturally reflexive verbs, and as passive otherwise, leaving anticausative interpretations out of the discussion for now. ${ }^{8}$ However, when structure (38b) is embedded under imperfective Aspect, a projection higher than Voice, see e.g. Rivero (1990), Alexiadou (1997) and others, a d. middle interpretation can also arise for these structures, (39).

$$
\left[\text { AspectP }_{\text {imperfective }}\left[\text { Middle/Voice } P_{\text {non-active }}\right]\right]
$$

The spell-out of non-active Voice in (38b) and (39) is regulated as follows, see (40), from Alexiadou, Anagnostopoulou \& Schäfer (2014), building on Embick (1998). A Voice head will be specified as bearing non-active features in contexts where it lacks a specifier. Otherwise it will be realized as default zero.

(40) Voice -> Voice[NonAct]/ No DP specifier

From this perspective then, what is subject to parametric variation is the unavailability of a Middle/Voice ${ }_{\text {non-active }}$ head across languages to build the core alternations we saw in section 1: English lacks such a head, while Greek has such a head. This suggests that there is no lexicon vs. syntax parameter and languages adhere to the principle in (8). Moreover, we predict that if a language makes use of a Greek type non-active Voice head for the type of alternations discussed here, its d. middles and reflexives will behave like unaccusatives.

Before we turn to the analysis of the English pattern of d. middles and reflexives, two issues should be tackled concerning the Greek d. middle. First of all, why are by-phrases licit in Greek d. middles? Second of all, what explains the contrast in (23-24) that led Tsimpli to propose that reflexives are unergatives in Greek? Both properties can actually be derived from the characterization of Middle

7. In other words, as argued for by Lekakou d. middles in Greek are built on the basis of a 'passive' + generic operator structure. That is what Lekakou called passive is re-interpreted here as Middle Voice.

8. I assume that roots belong to certain ontological classes, one of which is the group of naturally reflexive verbs. 
Voice offered in Alexiadou \& Schäfer (2013) and Spathas, Alexiadou \& Schäfer (to appear). Both Passive and Middle in these approaches are non-active Voice heads introducing an existentially bound implicit external argument. Unlike passive Voice, middle Voice does not obligatorily trigger a Disjoint Reference Effect. Thus it can both license by-phrases, agentive adverbs, and allow in (24), technically, control by the implicit agent of the Middle Voice, exactly as in structures with passive interpretation.

Turning now to English, Alexiadou \& Doron (2012) argued that since reflexives and d. middles are found in English with active morphology a Middle Voice can also surface with active morphology. In particular, the authors point out that while English lost its middle morphology, it is similar to Hebrew and Greek in that it contains a Middle Voice head, which, however, is realized as active. Alexiadou \& Doron subsumed this head under Middle Voice in order to capture the similarities between English, Hebrew and Greek as far as the meaning components of d. middles and reflexives are concerned. However, if we stick to the strict realizations conditions of the syntactic Voice head as e.g. proposed in Embick (1998), we are led to suggest that English simply does not employ a Voice head of the type in (38b) in d. middle and reflexive alternations. Crucially, the head involved in these AS alternations cannot be subsumed under the Middle Voice approach, since Middle Voice is a non-active Voice head. This leads to the proposal that active Voice morphology can only be associated with two possible structures: a structure which lacks Voice, as is the case of unmarked anticausatives, or an active Voice head that introduces/projects an external argument, as is arguably the case with unergative predicates. Since d. middles and reflexives are unergative predicates in English, this means that the single DP argument must be projected in Spec,VoiceP, hence the active morphology, contra Alexiadou \& Doron (2012). ${ }^{9}$

While this analysis is relatively uncontroversial in the case of reflexives, it is not clear that it can be straightforwardly assumed in the case of d. middles (see Schäfer 2008) for discussion. One problem is the following: as we have seen, there are several arguments that English d. middles are unergative predicates. However, according to (21), a d. middle interpretation is defined as the ascription of a dispositional property to the Patient/Theme argument. This would suggest that the single DP argument in the case of English d. middles should be projected as an internal argument, something that Schäfer (2008) takes to be the null hypothesis. But, we have seen that English d. middles must contain Voice, since they trigger Voice allomorphy (13-14). To account for this, I will build on Schäfer's analysis, according to which the DP argument of the d. middle moves from the internal position to the specifier of Voice, see e.g. Fujita (1994), cf. Ahn \& Sailor (to appear) $;{ }^{10}$ in

9. Note here that Schäfer (2008) defines this head as expletive Voice.

10. Note that Ahn and Sailor argue that in d. middles it is actually the vP that raises to Spec,VoiceP. Note also that all analyses that apply DP movement to Spec,VoiceP, as observed by Ahn and Sailor, face problems with explaining the presence of agentivity. I cannot enter a detailed discussion of this issue here, and I refer the reader to Schäfer (2008) for an analysis. For my purposes, it is sufficient to note that agentivity in d. middles is not of the same type as the one found in passives, and hence a different explanation is necessary. 
this sense, it can satisfy the requirement proposed in Lekakou with respect to the semantics of $d$. middle.

Schäfer (2008: 238) gives some evidence in favor of this movement analysis. Consider (41), (42), and (43):

(41) This kind of vases breaks easily.

(42) This kind of vases easily breaks.

(43) a. This book (*slowly) reads (slowly).

b. John (slowly) read (slowly) the book (slowly).

(41) is ambiguous between an anticausative and a d. middle reading. (42), however, is not ambiguous, it has the anticausative reading only. In (43), we see that while the adverb can appear following the external argument this is impossible in the case of the d. middle. The contrast in (43) suggests that Lekakou's definition of middle interpretation as the ascription of a dispositional property to the patient/theme argument is on the right track: in English adverbs of the type slowly in post-DP position receive an agentive interpretation only, see Alexiadou (1997), and Cinque (1999) for discussion and references. In other words, (43b) means that it was slow of John. ${ }^{11}$ Such an interpretation is unavailable for (43a), since the DP is a theme argument that lacks intentions. The contrast in (41) and (42) can be analyzed as follows: Alexiadou (1997) has argued that there are two places in the lower clausal domain in which adverbs of the type slowly can appear preserving the manner reading: either as complements of $\mathrm{V}$, within the $\mathrm{VP}$, thus appearing in sentence final position or as specifiers of Voice $\mathrm{P} / \mathrm{vP}$ thus appearing in pre-verbal position. The fact that a generic reading is blocked when the adverb appears in pre-verbal position suggests that in the case of $\mathrm{d}$. middles the DP must occupy Spec, VoiceP, hence the adverb cannot appear there, cf. Cinque (1999). Note that this type of approach assumes that adverbs as well as DPs occupy a unique specifier in the clausal architecture.

In Schäfer's system, which makes use of expletive Voice, the movement analysis does not lead to a situation in which the DP is assigned a second thematic role. ${ }^{12}$ We would crucially need to ensure that the active Voice head involved in English d.middles is of the type that requires an overt DP, but does not assign a thematic role to this DP. One could technically implement this by suggesting that theta-roles are assigned only on first merge, and subsequent movements do not add thematic roles, contra e.g. Hornstein (1999).

11. Note that such adverbs on their agent oriented reading are placed higher in the structure, see Cinque (1999), and Alexiadou (1997) for details.

12. Thanks to an anonymous reviewer for pointing this out. 


\section{Conclusions}

In this paper, I showed how distinct morpho-syntaxes can realize the same semantic category by focussing on the behavior of dispositional middles and reflexives in English and Greek. These two AS alternations have an unaccusative syntax in Greek, while they have an unergative syntax in English. I adopted a theory of Voice, according to which, there are three Voice heads implicated in AS alternations, active, passive and middle. Although passive was not the main focus of discussion here, the proposal was languages like Greek lack a passive Voice head, and languages like English do not seem to use Middle Voice for their core AS alternations, though they might use it when it comes to non-canonical passives such as adjectival passives and get-passives (see Alexiadou 2012 for discussion). It is also clear that underdeterminacy with respect to AS alternations will only be found in languages that have Middle Voice, such as Greek and not in languages such as English which have a passive vs. active system. Importantly, Middle Voice cannot be realized via active morphology: active morphology as realization of Voice is tied to the presence of Spec,VoiceP, following Embick (1998).

Now what about the other languages in table 1 ? Hebrew, as explicitly argued in Doron (2003) and Alexiadou \& Doron (2012), has both a passive, yielding a passive only interpretation, and a middle yielding d. middle and reflexive interpretations in its intensive template. In fact, it is predicted by systems that assume Passive and Middle Voice that there should be languages that have both Voice heads and Hebrew is a case in point.

As is well known, the status of German and Romance d. middles and reflexives has been the topic of much controversial discussion in the literature. Lekakou (2005) analyzes French d. middles as very similar to their Greek counterparts, suggesting that they will show properties of unaccusatives as expected. Similar considerations have been put forther for Romance reflexives, see e.g. Pesetsky (1995), Sportiche (1998), Embick (2004) among others for discussion and references, and Reinhart \& Siloni (2004) for an alternative. Recently, Sportiche (2014) has argued that $s e$ in French realizes middle Voice, cf. also Labelle (2008). In German, according to Schäfer (2008), all constructions involving sich are syntactically transitive, though some, e.g. d. middles and anticausatives, are semantically intransitive. We could argue, slightly departing from Schäfer's approach, that in German and Romance d. middles sich/se are projected in the specifier of a middle Voice head (which would correspond to his expletive Voice head). However, we would have to admit that its reflexive predicates have a distinct syntax, i.e. they are actually transitive structures, see Alexiadou, Schäfer \& Spathas (2014) for discussion.

\section{References}

Ackema, Peter; Schoorlemmer, Maaike (1994). «The Middle Construction and the Syntax-Semantics Interface». Lingua 93: 59-90.

Ahn, Byron; Sailor, Greg (to appear). «The Emerging Middle Class». In: Proceedings of The 46th Annual Meeting of the Chicago Linguistic Society (CLS 46). 
Alexiadou, Artemis (1997). Adverb Placement: A Case study in Antisymmetric Syntax. Amsterdam: John Benjamins.

Alexiadou, Artemis (1999). «On the Properties of some Greek Word Order Patterns». In: Alexiadou Artemis; Horrocks, Geoffrey; Stavrou, Melita (eds.). Studies in Modern Greek Syntax. Dordrecht: Kluwer, pp. 45-65.

Alexiadou, Artemis (2011). «Post-verbal Nominatives: An Unaccusativity Diagnostic under Scrutiny». In: Folli, Rafaella; Ulbrich, Christiane (eds.). Interfaces in Linguistics: New Research Perspectives. Oxford: Oxford University Press, pp. 56-77.

Alexiadou, Artemis (2012). «Non-canonical Passives revisited: Parameters of Nonactive Voice». Linguistics 50: 1079-110.

Alexiadou, Artemis (2013). «Where is non-active morphology? ». In Proceedings of the 20th conference on Head-driven phrase structure grammar. Stanford: CSLI Publications, pp. 244-262.

Alexiadou, Artemis; Anagnostopoulou, Elena (1999). «Tests for Unaccusativity in a Language without Tests for Unaccusativity». In: Proceedings of the 3rd international conference on Greek Linguistics. Athens: Ellinika Grammata, pp. 23-31.

Alexiadou, Artemis; Anagnostopoulou Elena (2004). «Voice Morphology in the Causative-inchoative Alternation: Evidence for a non unified Structural Analysis of Unaccusatives». In: Alexiadou, Artemis; Anagnostopoulou, Elena; Everaert, Martin (eds.). The Unaccusativity puzzle. Oxford: Oxford University Press, pp. 114-136.

Alexiadou, Artemis; Anagnostopoulou, Elena; Schäfer, Florian (2006). «The properties of anticausatives crosslinguistically». In: Frascarelli, Mara (ed.). Phases of Interpretation. Berlin: Mouton, pp. 187-212.

Alexiadou, Artemis, Anagnostopoulou, Elena; Schäfer, Florian (2015) External Arguments in Transitivity Alternations: A Layering Approach. Oxford: Oxford University Press.

Alexiadou, Artemis; Doron, Edit (2012). «The syntactic construction of two non-active Voices: Passive and Middle». Journal of Linguistics 48: 1-34.

Alexiadou, Artemis; Schäfer, Florian (2006). «Instrument subjects are Agents or Causers». In: Proceedings of WCCFL 25, pp. 40-48.

Alexiadou, Artemis; Schäfer, Florian (2013). «Towards a non-uniform analysis of naturally reflexive verbs». In Proceedings of WCCFL 31.

Alexiadou, Artemis; Schäfer, Florian; Spathas, Giorgos (2014). «Delimiting Voice in Germanic: on Object Drop and Naturally Reflexive Verbs». To appear in Proceedings of NELS 44.

Anagnostopoulou, Elena; Everaert, Martin (1999). «Towards a more complete Typology of Anaphoric Expressions». Linguistic Inquiry 30.1, 97-118

Bruening, Benjamin (2012). «By-Phrases in Passives and Nominals». Syntax 16: 1-41.

Cinque, Guglielmo (1999). Adverbs and Functional Heads. Oxford: Oxford University Press.

Collins, Chris (2005). «A Smuggling Approach to the Passive in English». Syntax 8: 81-120.

Condoravdi, Cleo (1989). «The Middle: where Semantics and Morphology meet». MIT Working Papers in linguistics 11: 18-30. 
Dimitriadis, Alexis; Que, Min (2009). «The Doubly-marked Reflexive in Chinese». In: Devi, Sobha Lalitha; Branco, António; Mitkov, Ruslan (eds.), Anaphora Processing and Applications. Berlin: Springer, pp. 80-90.

Doron, Edit (2003). «Agency and Voice: The Semantics of the Semitic Templates». Natural Language Semantics 11: 1-67.

Embick, David (1998). «Voice Systems and the Syntax/Morphology Interface». In MIT working papers in linguistics 32: Papers from the UPenn/MIT Roundtable on Argument Structure and Aspect, 41-72. MIT, Cambridge, Mass.

Embick, David (2004). «Unaccusative Syntax and Verbal Alternations». In: Alexiadou, Artemis; Anagnostopoulou, Elena; Everaert, Martin (eds.). The Unaccusativity Puzzle. Oxford: Oxford University Press, pp. 137-158.

Embick, David (2010). Localism vs. Globalism in Morphology and Phonology. Cambridge, Mass: MIT Press.

Fellbaum, Christiane (1986). On the Middle Construction in English. Bloomington, Indiana: Indiana University Linguistics Club.

Fujita, Koji (1994). «Middle, Ergative and Passive in English». In: MIT Working Papers in Linguistics 22, 71-90.

Goldberg, Adele (1997). «Making one's Way through the Data». In: Alsina, Alex; Bresnan, Joan; Sells, Peter (eds.). Complex Predicates. Stanford: CSLI, pp. 151-173.

Hornstein, Norbert (1999). «Movement and Control». Linguistic Inquiry 30: 69-96.

Iatridou, Sabine. (1988). «Clitics, Anaphors, and a Problem of Co-indexation». Linguistic Inquiry 19: 698-703

Kemmer, Suzanne (1993). The Middle Voice. Amsterdam: John Benjamins.

Kratzer, Angelika (1996). «Severing the External Argument from its Verb». In: Rooryck, Johan; Zaring, Laurie (eds.). Phrase Structure and the Lexicon. Kluwer, Dordrecht, pp. 109-137.

Labelle, Marie (2008). «The French Reflexive and Reciprocal se». Natural Language and Linguistic Theory 26: 83-876.

Lekakou, Maria (2005). In the Middle, Somehow Elevated. UCL, doctoral dissertation.

Levin, Beth (1993). English Verb Classes and Alternations: A Preliminary Investigation. Chicago: University of Chicago Press.

Lohndal, Terje (2014). Phrase Structure and Argument Structure: A Case Study of the Syntax-Semantics Interface. Oxford: Oxford University Press.

Marantz, Alec (1984). On the Nature of Grammatical Relations. Cambridge, Mass.: MIT Press.

Marantz, Alec (1992). «The Way-construction and the Semantics of Direct Arguments in English: A Reply to Jackendoff». In: Stowell, Timothy; Wehrli, Eric (eds.). Syntax and the Lexicon. San Diego: Academic Press, pp. 179-188.

Marantz, Alec (2013). «Locating the Verbal Root». Paper presented at the 25th Scandinavian Conference of Linguistics, Iceland.

Markantonatou, Stella (1992). The Syntax of the Modern Greek Noun Phrases with a Deverbal Nominal Head. University of Essex, doctoral dissertation.

Merchant, Jason (2013). «Voice and Ellipsis». Linguistic Inquiry 44: 77-108.

Papangeli, Dimitra (2004). The Morpho-syntax of Argument Realization: Greek Argument Structure and the Lexicon-Syntax Interface. LOT, doctoral dissertation.

Pesetsky, David (1995). Zero Syntax. Cambridge, Mass.: MIT Press. 
Pitteroff, Marcel (2014). Non-canonical lassen Middles. University of Stuttgart, doctoral dissertation.

Reinhart, Tanya; Siloni, Tal (2004). «Against the Unaccusative Analysis of Reflexives». In: Alexiadou, Artemis; Anagnostopoulou, Elena; Everaert, Martin (eds.). The Unaccusativity Puzzle. Oxford: Oxford University Press, pp. 288-331.

Reinhart, Tanya; Siloni, Tal (2005). «The Lexicon-Syntax Parameter: Reflexivization and Other Arity Operations». Linguistic Inquiry 36: 389-436.

Rivero, Maria-Luisa (1990). "The Location of Non-Active Voice in Albanian and Modern Greek». Linguistic Inquiry 21: 135-146.

Schäfer, Florian (2008). The Syntax of (Anti-)Causatives. External Arguments in Change-of-state Contexts. Amsterdam: John Benjamins.

Schäfer, Florian (2009). "The Causative Alternation». Language and Linguistics Compass 3.2: 641-681.

Schäfer, Florian (2012). «Two Types of External Argument Licensing - the Case of Causers». Studia Linguistica 66: 128-180.

Sells, Peter; Zaenen, Annie; Zec, Draga (1987). «Reflexivization Variation: Relations between Syntax, Semantics, and Lexical Structure». In: Iida, Masayo; Wechlser, Stephen, Zec, Draga (eds.). Working Papers in Grammatical Theory and Discourse Structure: Interactions of Morphology, Syntax, and Discourse. Stanford: CSLI Publications, pp. 169-238.

Sioupi, Athina (1998). Domes Mesis Diathesis. Mia Sigritiki Meleti Elinikis-Germanikis (Middle Constructions: A Comparative Study of Greek and German). University of Athens, doctoral dissertation.

Smyrniotopoulos, Jane (1992). Lexical Passives in Modern Greek. New York: Garland. Stephens, Nola (2007). «Agentive for Phrases in Middles». Paper presented at the LSA Meeting, Anaheim, CA.

Stroik, Thomas (1992). «Middles and Movement». Linguistic Inquiry 23: 27-137.

Spathas, Giorgos (2010). Focus on Anaphors. LOT, doctoral dissertation.

Spathas, Giorgos; Alexiadou, Artemis; Schäfer, Florian (To appear). «Middle Voice and Reflexivization: Afto-Prefixation in Greek». Natural Language and Linguistic Theory.

Sportiche, Dominique (1998). Partitions and Atoms of Clause Structure: Subjects, Agreement, Case and Clitics. London/New York: Routledge.

Sportiche, Dominque (2014). «French Reflexive se: Binding and Merge Locality». In: Aboh, Enoch; Guasti, Maria Teresa; Roberts, Ian (eds.). Locality. New York: Oxford University Press.

Tsimpli, Ianthi-Maria (1989). «On the Properties of the Passive Affix in Modern Greek». UCL Working papers in Linguistics 1: 235-260.

Zombolou, Katerina (2004). Verbal Alternations in Greek: a Semantic Analysis. University of Reading, doctoral dissertation. 